\title{
Place-Based Analysis of Satellite Time Series Shows Opposing Land Change Patterns in the Copperbelt Region of Zambia
}

\author{
Sana Munawar ${ }^{1, * \mathbb{C}}$, Achim Röder ${ }^{1} \mathbb{C}$, Stephen Syampungani ${ }^{2}$ and Thomas Udelhoven ${ }^{1}$ \\ 1 Department of Environmental Remote Sensing and Geoinformatics, Universität Trier, 54296 Trier, Germany; \\ roeder@uni-trier.de (A.R.); udelhove@uni-trier.de (T.U.) \\ 2 Oliver R. Tambo African Research Initiative (ORTARChI) Environment and Development, Copperbelt \\ University, Kitwe 1001, Zambia; ssyampungani@yahoo.com \\ * Correspondence: s6ssmuna@uni-trier.de
}

check for updates

Citation: Munawar, S.; Röder, A.; Syampungani, S.; Udelhoven, T. Place-Based Analysis of Satellite Time Series Shows Opposing Land Change Patterns in the Copperbelt Region of Zambia. Forests 2022, 13, 134. https://doi.org/10.3390/ f13010134

Academic Editor: Steven L. Petersen

Received: 21 December 2021

Accepted: 14 January 2022

Published: 17 January 2022

Publisher's Note: MDPI stays neutral with regard to jurisdictional claims in published maps and institutional affiliations.

Copyright: (C) 2022 by the authors. Licensee MDPI, Basel, Switzerland. This article is an open access article distributed under the terms and conditions of the Creative Commons Attribution (CC BY) license (https:/ / creativecommons.org/licenses/by/ $4.0 /)$.

\begin{abstract}
The process of land degradation needs to be understood at various spatial and temporal scales in order to protect ecosystem services and communities directly dependent on it. This is especially true for regions in sub-Saharan Africa, where socio economic and political factors exacerbate ecological degradation. This study identifies spatially explicit land change dynamics in the Copperbelt province of Zambia in a local context using satellite vegetation index time series derived from the MODIS sensor. Three sets of parameters, namely, monthly series, annual peaking magnitude, and annual mean growing season were developed for the period 2000 to 2019. Trend was estimated by applying harmonic regression on monthly series and linear least square regression on annually aggregated series. Estimated spatial trends were further used as a basis to map endemic land change processes. Our observations were as follows: (a) 15\% of the study area dominant in the east showed positive trends, (b) $3 \%$ of the study area dominant in the west showed negative trends, (c) natural regeneration in mosaic landscapes (post shifting cultivation) and land management in forest reserves were chiefly responsible for positive trends, and (d) degradation over intact miombo woodland and cultivation areas contributed to negative trends. Additionally, lower productivity over areas with semi-permanent agriculture and shift of new encroachment into woodlands from east to west of Copperbelt was observed. Pivot agriculture was not a main driver in land change. Although overall greening trends prevailed across the study site, the risk of intact woodlands being exposed to various disturbances remains high. The outcome of this study can provide insights about natural and assisted landscape restoration specifically addressing the miombo ecoregion.
\end{abstract}

Keywords: MODIS; degradation; regeneration; miombo woodland; shifting cultivation; sub-Saharan Africa

\section{Introduction}

Understanding human-induced land degradation has become essential in order to identify drivers of loss of ecosystem services and reduced land productivity [1]. Land degradation can manifest itself in the form of reduced forest cover, colonization by invasive species, grassland degradation, declined crop yields, soil erosion, and salinization. In addition, some of the far-reaching impacts can include threatened food security, impoverishment of indigenous communities, unemployment, and unstable local and national economy [2]. Globally, 24\% of the land area has been reported to be degraded [3], and in the case of drylands, the Millennium Ecosystem Assessment [4] reports a degradation of $10 \%$ to $20 \%$. This can result in serious implications for the 1.5 billion people who depend on these lands for their survival and sustenance [3]. The issue of land degradation and its remediation has also been targeted in the 15th SDGs (Sustainable Development Goals) adopted at the United Nation Sustainable Development Summit in 2015.

Drivers of land degradation [5] have been categorized as follows: increased aridity (prolonged dry periods, high temperature), agricultural intensification and expansion 
(including over grazing), urbanization and infrastructure (including roads, settlements, irrigation, and industries such as mining) and wood extraction. Climatic factors, especially droughts, can exacerbate existing degradation and even slow down recovery [6]. There are numerous other indirect variables controlling land change processes, such as global economic policies, market trends (mineral prices), land management schemes, natural resource policies, and poverty and/or land ownership conflicts [7].

This scenario is typically reflected in sub-Saharan African countries like Zambia. SubSaharan Africa is highly susceptible to land degradation [8]. The limited studies [9-13] on land cover changes in sub-Saharan Africa are either confined in their spatial scale or in the assessment period. In order to integrate land degradation in the national environmental policy and management programs, it is essential to address drivers of land change and their spatial and temporal dynamics. It is noteworthy here to mention that Zambia was one of the pilot countries to be considered for REDD+ (Reducing Emissions from Deforestation and Forest Degradation) program in 2010. One of the earliest vegetation monitoring studies in Zambia covered the Copperbelt province [14].

\section{Study Area}

This paper focuses on the Copperbelt province of Zambia, located in the central north (Figure 1) on the Central African plateau, and covering an area of $31,328 \mathrm{~km}^{2}$. Geographically, Zambia falls in the tropical region, between $8^{\circ} \mathrm{S}$ and $18^{\circ} \mathrm{S}$, however the climatic conditions are driven more by altitude; where Copperbelt lies between the elevation $900 \mathrm{~m}$ to $1500 \mathrm{~m}$ above sea level (asl). There are three distinct seasons controlled by north and south movement of the intertropical convergence zone (ITCZ). The warm and wet period is between November and April, cool and dry between May and August with July being the coolest month, and hot and dry between September and October, with October as the hottest time of the year [15]. Based on rainfall patterns and edaphic conditions, Zambia is divided into three agro-ecological zones; of which the Copperbelt belongs to zone III that is characterized by high precipitation (annual average of $1200 \mathrm{~mm}$ ), low fertility, and acidic and leached soils [16].

Copperbelt is part of the central wet miombo woodland zone, where Brachystegia spiciformis, Isoberlinia angolensis, and Julbernadia paniculata are the dominating tree species, found interspersed with patches of flooded grasslands. Maize, cassava, wheat, soybeans, sweet potatoes, and groundnuts are the main crops produced mainly in the rainy season at subsistence level across the Copperbelt. There are ongoing land use/changes such as end of dry season fires, shifting cultivation, charcoal production, logging, industrialization, urbanization, and increasing settlements. A significant part of the population, rural and urban, depend on woodland harvest for around 70\% of their energy needs [17]. Mining, which serves as a major contributor to the national economy, is one of the prominent activities in this region as well [18]. In general, the Zambian Forestry sector has a 5.4\% [19] share in gross domestic product (GDP) and provides 1.4 million jobs [20]. Such economic dependence has led to high deforestation rates of $1.5 \%$ per year. It is one of the highest in the sub-Saharan African region, leading to massive exploitation of the miombo woodlands [21] and contributing 3\% to the global greenhouse gas (GHG) emissions [22].

The Copperbelt province has experienced substantial degradation and exploitation of miombo woodlands [23]. This has been compounded by limited land restoration programs that target drivers specific to the Copperbelt region. Monitoring land change on continental or global scale, using coarse spatial resolution $(\sim 1 \mathrm{~km})$ data, can lead to bias by underestimating local scale land change drivers and overestimating dominant patterns. Land use change is highly region specific, requiring spatially explicit information. Subsequently, during land management implementation at the national and sub-national level, higher resolution data are needed to connect it with real land use change processes that match environmental protection targets defined at various strata of policymaking. Even multi-temporal static land cover maps are not sufficient to monitor land changes in terms of capturing subtle processes. In addition, no differentiation is highlighted between: natural 
undisturbed forests/recovered forests and managed plantations, shifting cultivation and pivot irrigation, fallow land from bare land, and, lastly, mosaic or fragmented landscape are mostly classified as a single land use type. A practice that is classic and a major driver of deforestation in this region is shifting cultivation (chitemene), which is highly driven by endemic circumstances (tribal ownership and informal economy) and might even need district level monitoring [24]. For instance, block 'chitemene' cultivation plots are more common in Copperbelt as compared to circular 'chitemene', which are prevalent in the Northern province.
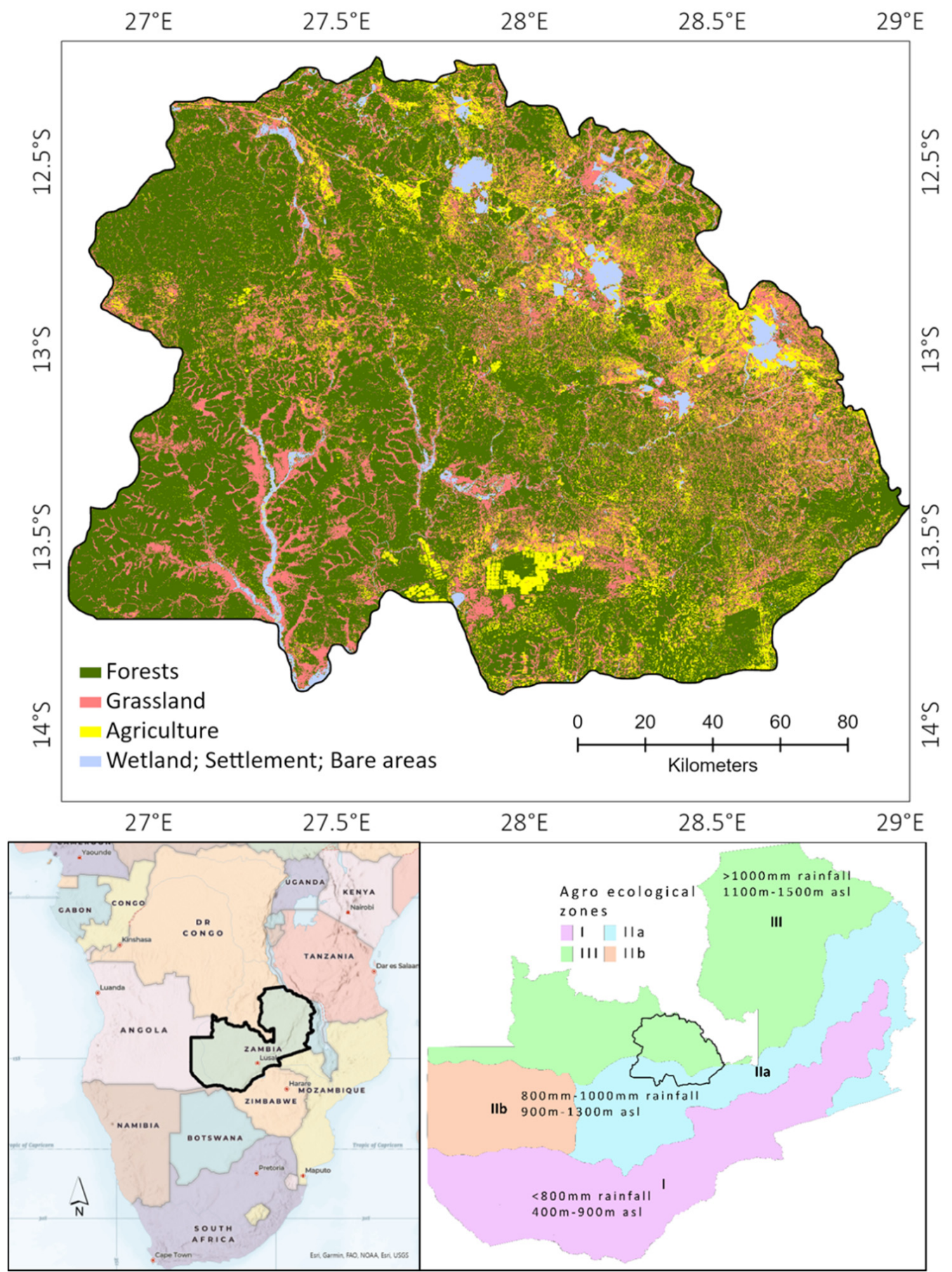

Figure 1. Study area of the Copperbelt (top image) along with its land cover classification for the year 2014 taken from ILUA (Integrated Land Use Assessment [13]). It borders Democratic Republic of Congo in the north and east (bottom image). According to the scale in the map, $1 \mathrm{~cm}$ equals $10 \mathrm{~km}$. 
Satellite-based earth observation data, such as surface reflectance and derived data products, have been shown to be capable of tracing the development of terrestrial surfaces. It is a well-established practice to integrate surface reflectance derived vegetation index time series in environmental monitoring strategies [25]. They provide objective, repetitive, and synoptic observation data that are required for capturing long-term trends and short-term disturbances across large areas [26,27]. The two most prominent and suitable long-term archives that exist are coarse spatial-high temporal resolution MODIS and medium spatiallow temporal resolution Landsat. For monitoring studies covering a long temporal period, trade-offs always have to be made in terms of dense temporal resolution and coarse spatial resolution. The MODIS time series was used in our study as opposed to the Landsat time series, mainly due to (1) high cloud cover in Landsat imagery over subtropical regions during the wet season; and (2) irregular Landsat scenes that do not account for seasonality, in which case the fitting of Fourier polynomials would still not be enough because the series is not dense enough.

Trend assessments of time series data of numerous biophysical indicators have been developed to assess long-term land use trajectories [28]. For instance, refs. [29,30] used MODIS to monitor long term changes in tree cover of semi-arid biomes of South Africa and changes in vegetation in the Sahel respectively. The authors in [31,32] used the Landsat archive to assess cultivation patterns over the Angolan Miombo belt and long-term land cover changes in Zambia respectively. The authors in [33] used MODIS and Landsat both to analyze degradation processes in South West Niger. The authors in [34] identified shifts in vegetation productivity in African savannahs by applying BFAST on GIMMS NDVI. The authors in [6] used BFAST on the Landsat-derived moisture index to detect vegetation degradation in the Kavango-Zambezi Transfrontier Conservation Area (KAZA). The authors in [35] monitored Barotse floodplain in upper Zambezi River Basin for trend assessment in inundation extent, and [36] mapped land change syndromes in the Himalayan region using BFAST algorithm on MODIS EVI.

Our study proposes a semi-automatic methodology for using remotely sensed times series to map land degradation, regeneration, and productivity patterns at provincial (sub-national) level.

Covering the full Copperbelt province, we seek to characterize and quantify land degradation in a local context, by addressing the following objectives: (1) calculate longterm trends over Copperbelt using hyper-temporal data, (2) use calculated trend patterns to map endemic land change dynamics, and (3) evaluate mapped dynamics in the context of underlying change drivers.

Our methodology relies on MODIS EVI time series to identify spatio-temporal trends, while open-source data sets are utilized for interpretation. This ensures easy transferability and adaption to regions with comparable geographical and ecological characteristics.

\section{Materials and Methods}

\subsection{Time Series Data and Indicators}

MODIS satellite instrument (described below) was used to derive three vegetation indicators over a period of twenty years. Other types of data were also incorporated to be used as an additional layer for analysis and interpretation for the detected changes. These data sets include land cover type, Global Forest Cover Change, road and river shapefile, national park inventory, managed forest reserves, restorative plantations, and socio-economic data (population, national growth indicators, fertilizer/pesticide use, mining production, and agricultural yield).

\subsubsection{MODIS (MODerate Resolution Imaging Spectroradiometer)}

This study used the MODIS vegetation index product (Collection 6 level 3, MOD13Q1), developed using red $(0.62 \mu \mathrm{m}$ to $0.67 \mu \mathrm{m})$ and (near infrared) NIR $(0.84 \mu \mathrm{m}$ to $0.88 \mu \mathrm{m})$ bands with $250 \mathrm{~m}$ spatial resolution. MOD13Q1 products are constrained view maximum value 16-day composites made from 8 -day bidirectional surface reflectance granules. The 
8-day product has been corrected for molecular scattering, aerosol, and ozone absorption. The 16-day composites use the criteria of low clouds, low viewing angle, and highest index values to select the best available pixel. There is a standardized algorithm to generate spatially and temporally consistent MODIS data products, which are constantly assessed for their accuracy and long-term integrity [37]. EVI (Enhanced Vegetation Index) was extracted to be used in the study; in addition to the red and NIR channels, EVI uses the blue band with wavelength $0.46 \mu \mathrm{m}$ to $0.48 \mu \mathrm{m}$ and $500 \mathrm{~m}$ spatial resolution.

EVI data covering the period from 2000 and 2019 were downloaded in GeoTIFF format using the AppEEars (Application for Extracting and Exploring Analysis Ready Samples) online tool [38]. Downloaded data were pre-processed using the Whittaker smoother [39] with lambda as 500 to convert 16-day data to monthly composites and to fit the data to the upper envelope for correcting any undetected clouds. The function 'whittaker.raster' in R-3.6.2 was applied [40].

\subsubsection{Parameter Derivation and Trend Estimation}

The wavelength of NIR is sensitive to vegetation-related processes, such as changes in greenness of the vegetated surface over time. The ratio of reflected NIR by spongy mesophyll and absorption of red wavelength by chlorophyll in leaves is correlated to different parameters such as biomass, forest cover, and vegetation health. Higher reflection of NIR will lead to higher EVI values, which signifies high biomass and productivity [25,41] This information collectively can be used as a proxy for direct drivers of land degradation and changes in forested landscapes. Table 1 shows the parameters derived using MODIS EVI time series data and their application in land change mapping.

Table 1. Original data set and its derivation for time series analysis.

\begin{tabular}{ccc}
\hline Original Time Series & Parameters & Derivation \\
\hline \multirow{3}{*}{ Bi monthly } & Monthly composites & Harmonic model \\
\cline { 2 - 3 } & Peaking magnitude & Annual maximum EVI \\
\cline { 2 - 3 } & ${ }^{1}$ MGS & Average EVI between ${ }^{2}$ SOS and ${ }^{2}$ EOS \\
\hline
\end{tabular}

${ }^{1}$ Mean growing season, ${ }^{2}$ Start and end of season.

Trend on monthly time series was calculated using the BFAST (Breaks for Additive Seasonal and Trend) algorithm developed by [42]. It is an additive decomposition model using piecewise linear trend and fitting of harmonic terms. Thus, for every EVI value at a particular time, the regression algorithm has the following components: intercept, slope, amplitude, phase, and residuals. Ordinary least squares regression was applied to estimate slope values (trend).

To derive phenological metrics, annual peaking magnitude and mean growing season (MGS), monthly series were fitted with a cubic smoothing spline and interpolated to daily values. Then, the start and end of season (SOS and EOS) were estimated using the derivative of the seasonal curve [43]. This approach assumes SOS and EOS as mid points for spring greenup and autumn senescence. Following this, MGS was calculated as average EVI value of the days between SOS and EOS and peak was calculated as maximum EVI value between SOS and EOS, respectively. Trend for MGS and peak was calculated through estimation of linear least square regression. Trend estimation of all three parameters was carried out against a significance level of $5 \%$ or $p<0.05$ [44]. This was justified by an average of $19 \%$ change in EVI values during the evaluation period, which was considered as a significant change. The aforementioned analysis was carried out in R-3.6.2 [45] using the 'greenbrown' library [46]. The output of all slope estimations were raster layers showing either positive (greening) or negative (browning) trends. Calculated slope values were categorized into strong $(> \pm 0.01)$ and weak $(< \pm 0.01)$. In order to compensate for Type I error (false positive), referred to here as pixels with only one significant trend, an additional map was derived to show positive and negative trend in relation to the three parameters combined. Only 
pixels with two or more significant trends were selected based on the assumption that they are depicting real land changes. This trend map was used as a basis to map land change processes.

\subsection{Additional Data}

To link calculated trend patterns with land change processes, various additional data sets were used. Information on land cover type, especially forest area and cultivation fields, was retrieved from $30 \mathrm{~m}$ resolution land cover maps produced by the ILUA [13] project in Zambia for 2000, 2010, and 2014. Additionally, EVI and NDMI (Normalized Difference Moisture Index), for Landsat 7 and 8 images, was calculated on Google Earth Engine using the code editor for the years 2000 and 2019. Deforestation and tree canopy cover data, at $30 \mathrm{~m}$ resolution, were provided by Global Forest Change data set [47]. Some features like pivot irrigation and mines were easily visible and therefore hand digitized on Google earth. Shapefiles for road, rail, and rivers were acquired from open street maps [48]. Plantation sites were digitized on google earth using the open spatial information provided by the organization 'WeForest' (https://www.weforest.org/project/copperbelt-forestsfarms, accessed on 15 September 2021). All socioeconomic data were downloaded from the official website of Zambia Central Statistical Office (https: / / zambia.opendataforafrica.org/, accessed on 28 October 2021). High-resolution imagery from Google Earth and Bing maps was also visualized for interpretation.

\subsection{Assigning Land Change Processes}

We used a semi-automated approach that comprises automated time series analysis as described above, followed by iterative, rule-based association of environmental context using auxiliary data sources. The first step was to determine the land use type for start (2000) and end (2019) of evaluation period. Figure 2 gives an overview of how land use type was categorized using the trend map as basis. Woodland extent was determined using land cover map from ILUA data, shifting cultivation plots were identified using deforestation data and Landsat derived EVI and NDMI for the years 2000 and 2019; where plots were visible as dark areas. Extent of fragmentation in forested landscape (referred to in this paper as mosaic containing mixture of woodland, grassland, and shifting cultivation plots) was identified using Global tree canopy cover data [47] as follows: canopy cover below the approximate threshold of $40 \%$ was considered as mosaic. In addition, Landsat imagery was also visualized where mixture of bright (woodland) and dark areas (shifting plots) constituted mosaic areas.

If the trend showed a greening pattern over mosaic areas it was assumed that woodland was the dominant land feature. If the trend showed a browning pattern, then it meant shifting cultivation was dominant. Furthermore, mosaic areas with more significant greening pixels meant these areas are undergoing higher regeneration than the areas with less significant greening pixels. If woodland to mosaic class showed a greening pattern, then an initial conversion from woodland to shifting, and then to mosaic, was assumed. Trends over designated forest reserves were always assumed to be driven by management activities, regardless of it being positive or negative (see discussion for more details). The three trend parameters (harmonic, peak, and MGS) were analyzed individually as well as in combinations by deriving a color-coded map with only those pixels where any two parameters exhibited the same significant trend, and also where all three parameters had the same significant trend. The scheme in Table 2 was followed to translate the information from pixels to zones, where zones represent groups of pixels with similar spatial properties in terms of land use. 


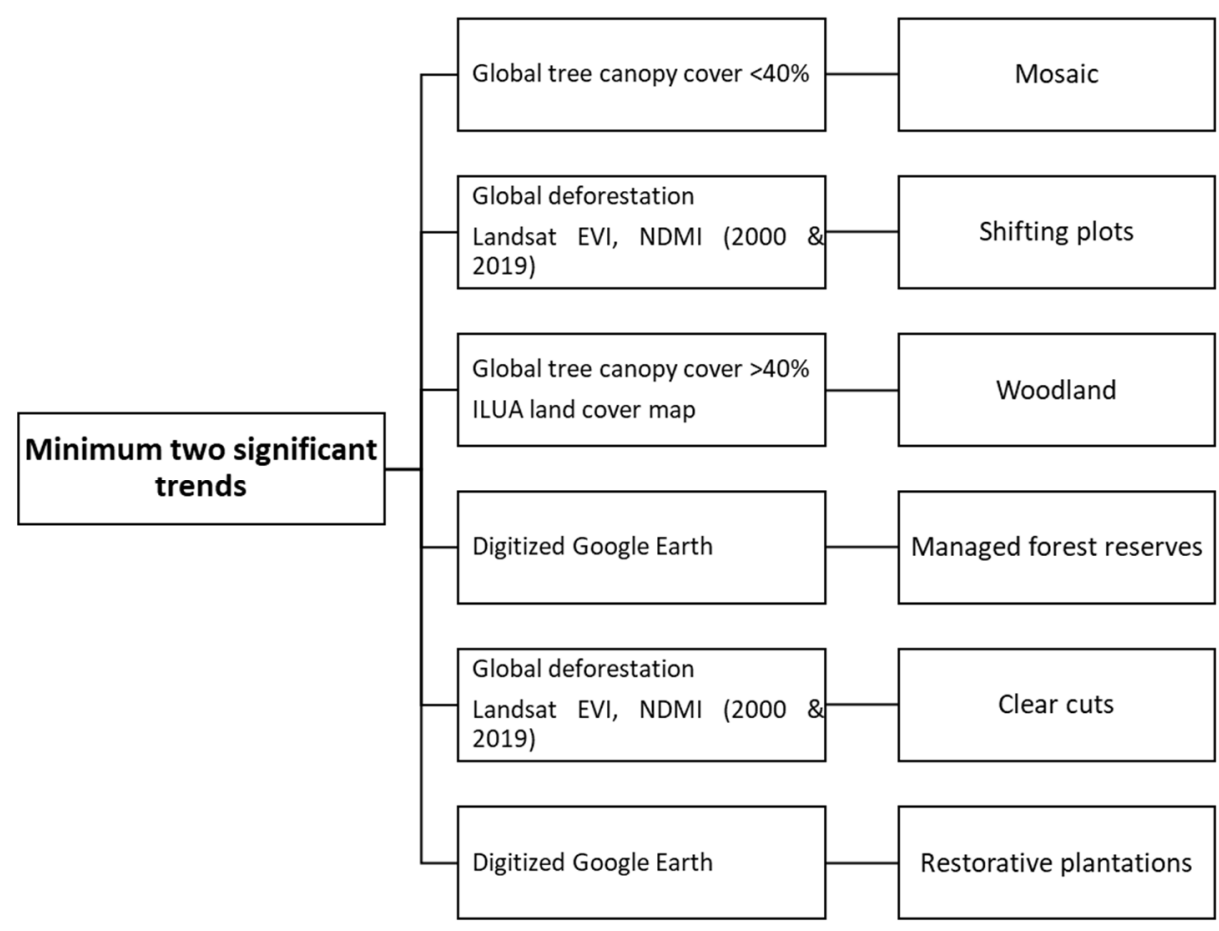

Figure 2. Systematic scheme used to assign land use type. "Minimum two significant trend" means the trend map with pixels having two and three significant trend patterns.

Table 2. Framework for assigning land use processes.

\begin{tabular}{|c|c|}
\hline Land Use Type 2000 & Land Use Type 2019 \\
\hline \multicolumn{2}{|c|}{ Land use change } \\
\hline \multirow{4}{*}{ Natural woodland } & b Shifting plots \\
\hline & g Pivot \\
\hline & $1 \mathrm{~g}$ Pivot \\
\hline & $1 \mathrm{~g}$ Mosaic \\
\hline \multirow{3}{*}{ Shifting plots } & g Pivot \\
\hline & g Mosaic \\
\hline & g Restorative plantation \\
\hline Mosaic & b Shifting plots \\
\hline \multicolumn{2}{|c|}{ Similar land use } \\
\hline \multirow{2}{*}{ Natural woodland } & ${ }^{\mathrm{b}}$ Exploitation \\
\hline & g Natural regrowth \\
\hline \multicolumn{2}{|c|}{ m Shifting plots } \\
\hline \multicolumn{2}{|c|}{$\mathrm{m}$ Mosaic } \\
\hline \multirow{2}{*}{ Managed forest reserves } & b Clear cuts \\
\hline & g Conservation \\
\hline
\end{tabular}

${ }^{1}$ Intermediate conversion to shifting plots, ${ }^{\mathrm{b}}$ Browning trend, ${ }^{\mathrm{g}}$ Greening trend, ${ }^{\mathrm{m}}$ Mixed trend.

\section{Results}

\subsection{Trend Analysis}

Table 3 shows the proportion of greening and browning trends for the three parameters individually. Most of the slopes are positive, with MGS showing the highest number of greening pixels, and peak showing the highest number of browning pixels. Non-significant 
pixels were assumed as stable in terms of land use. According to Table 3 the regression model performed better (higher number of significant pixels) in assessing trends of annually aggregated series (peak and MGS) as compared to seasonal harmonic series.

Table 3. Greening and browning distribution for the three trend parameters individually.

\begin{tabular}{cccc}
\hline Trend & MGS & Peak & Harmonic \\
\hline Browning & $3 \%$ & $7 \%$ & $4 \%$ \\
\hline Non-significant (stable) & $70 \%$ & $77 \%$ & $89 \%$ \\
\hline Greening & $27 \%$ & $16 \%$ & $7 \%$ \\
\hline
\end{tabular}

Figure 3 shows positive and negative trend in relation to the three parameters combined. Pixels with two greening trends were the most prominent amounting to $12 \%$, and pixels with three greening trends summed up to 3\%. The least common pattern was for three browning trends, being only $1 \%$. Pixels with two browning trends were $2 \%$. More significant trends in the form of major hotspots were observed in the east of Copperbelt with most of them being positive. The west and southeast parts of the study site experienced more negative trends, with many isolated groups of pixels scattered throughout. Some hotspots for negative trends (central north and towards northeast) over open pit mines were eliminated from further analysis. Although mines have a high contribution to deforestation, they represent a static and permanent land cover change rather than a dynamic one.

For two significant trend parameters, highest agreement was observed between MGS and peak (annually aggregated series) for greening in approximately $10 \%$ and browning in $1.5 \%$ of the pixels. The combination of harmonic trend with other annual parameters was as follows: in the greening category harmonic and MGS was more common (1.6\%) while in the browning category harmonic and peak were more common (0.5\%) (Figure 4$)$.

Figure 5 shows that weak positive slopes occurred more frequently compared to weak negative slopes. On the other hand, strong negative slopes, albeit only $1 \%$, were more common than strong positive slopes, which were only $0.2 \%$. This demonstrates that most land changes in Copperbelt are subtle. This is even more profound over mosaic (heterogeneous) pixels where mixed land dynamics give rise to complex trend patterns. Strong trend slopes were explicitly observed in areas that were managed, for instance, pivot irrigation plots, forest reserves, and sites that underwent restorative plantations on small hold farms.

\subsection{Land Change Dynamics}

Based on the scheme defined in Table 2, a total of 12 classes were derived that showed the classification of land types in 2000 and 2019, these classes were then summarized into six major land change processes, referred to in this paper as land change dynamics (Table 4). A color-coded map was then created to depict the spatial distribution of six land change dynamics (Figure 6), excluding the sites for open pit mines. 

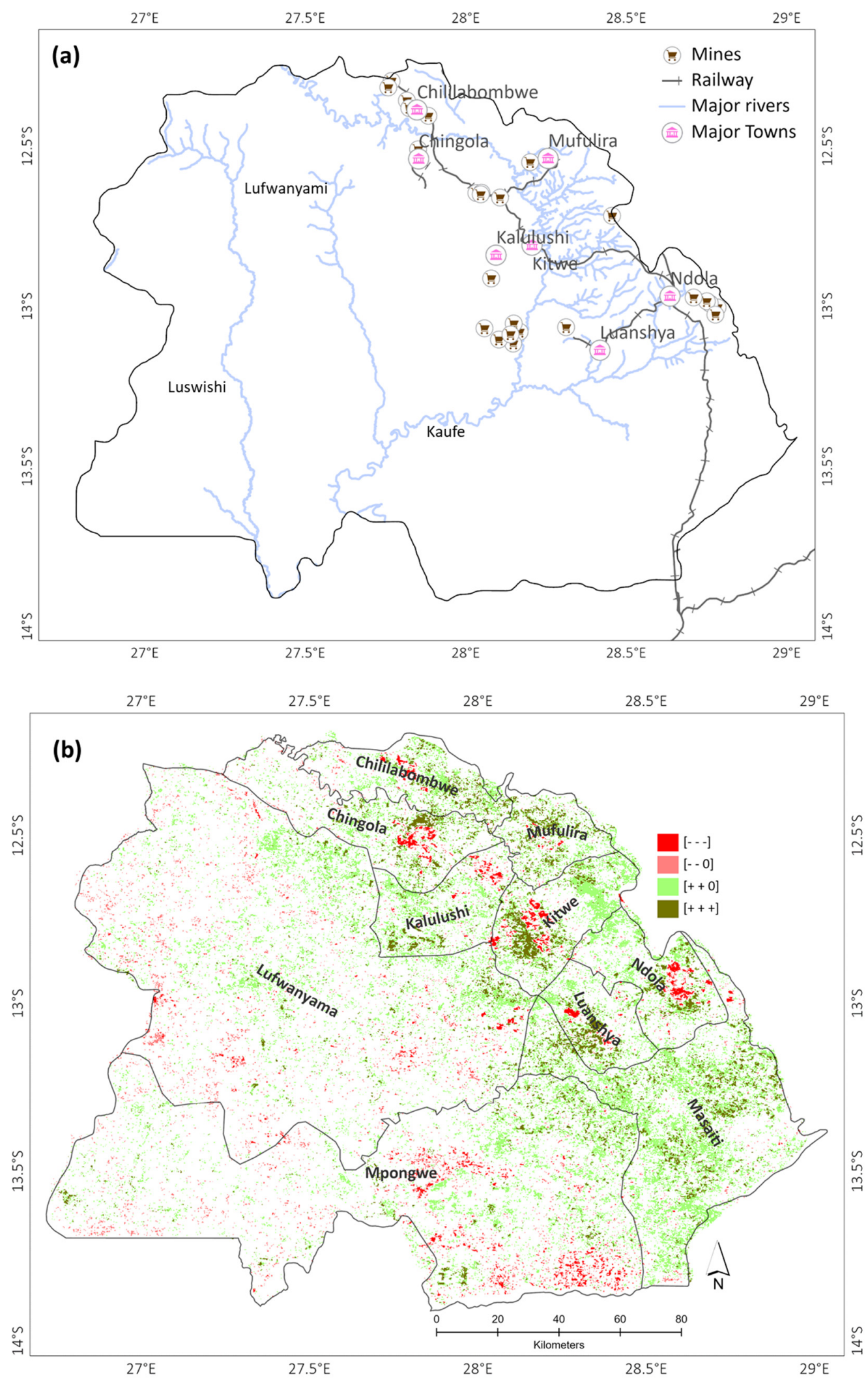

Figure 3. (a) Overview of major towns, railway, mines, and rivers in Copperbelt for spatial orientation. Mines were hand digitized on Google Earth, whereas railway, rivers, and towns were taken from open street map. (b) Spatial distribution of two and three significant trend patterns for all parameters: MGS, Peak, Harmonic combined (b). (-): browning, (+): greening, (0): no significant trend. According to the scale in the map, $1 \mathrm{~cm}$ equals $10 \mathrm{~km}$. 


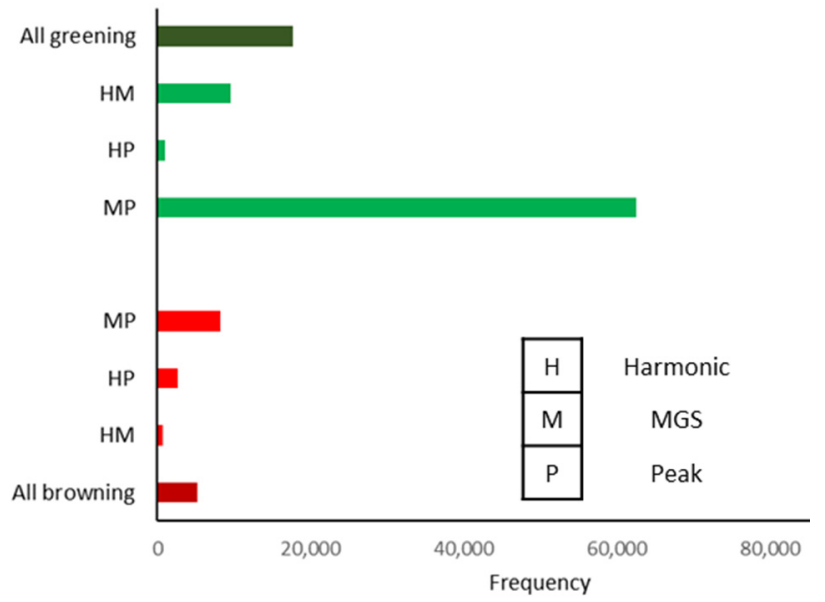

Figure 4. Distribution of trend parameters in relation to each other.

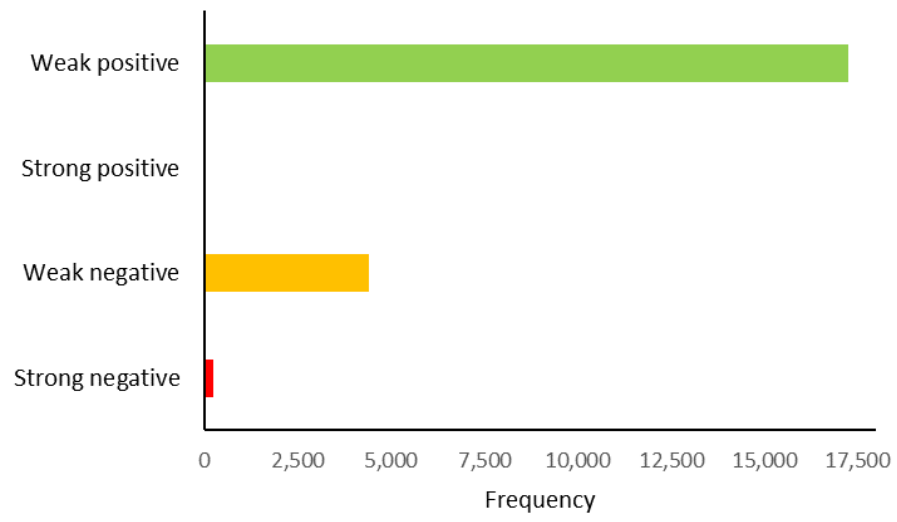

Figure 5. Distribution of weak and strong slopes.

Table 4. Major classification of land change dynamics along with the sub categories.

\begin{tabular}{cc}
\hline Main Class: Land Change Dynamic & Sub Class \\
Pivot agriculture & ${ }^{10}$ Shifting plots to Pivot \\
\cline { 2 - 2 } & ${ }^{12}$ Pivot \\
\hline Degradation (onset) productive woodland & ${ }^{11}$ Woodland to Pivot \\
\hline New encroachment & ${ }^{5}$ Woodland \\
\hline Degradation (ongoing) productive land & ${ }^{8}$ Woodland to Shifting plots \\
\cline { 2 - 2 } Managed conservation & ${ }^{7}$ Mosaic to Shifting plots \\
\hline Natural regeneration & ${ }^{3}$ Forest reserves \\
\cline { 2 - 2 } & ${ }^{6}$ Shifting plots to Plantations \\
\cline { 2 - 2 } & ${ }^{4}$ Woodland to Mosaic \\
\cline { 2 - 2 } & ${ }^{2}$ Shifting plots to Mosaic \\
\hline
\end{tabular}

$\overline{1-12}$ The frequency of spatial occurrence of each sub class, with 1 being most common to 12 being the least common. 


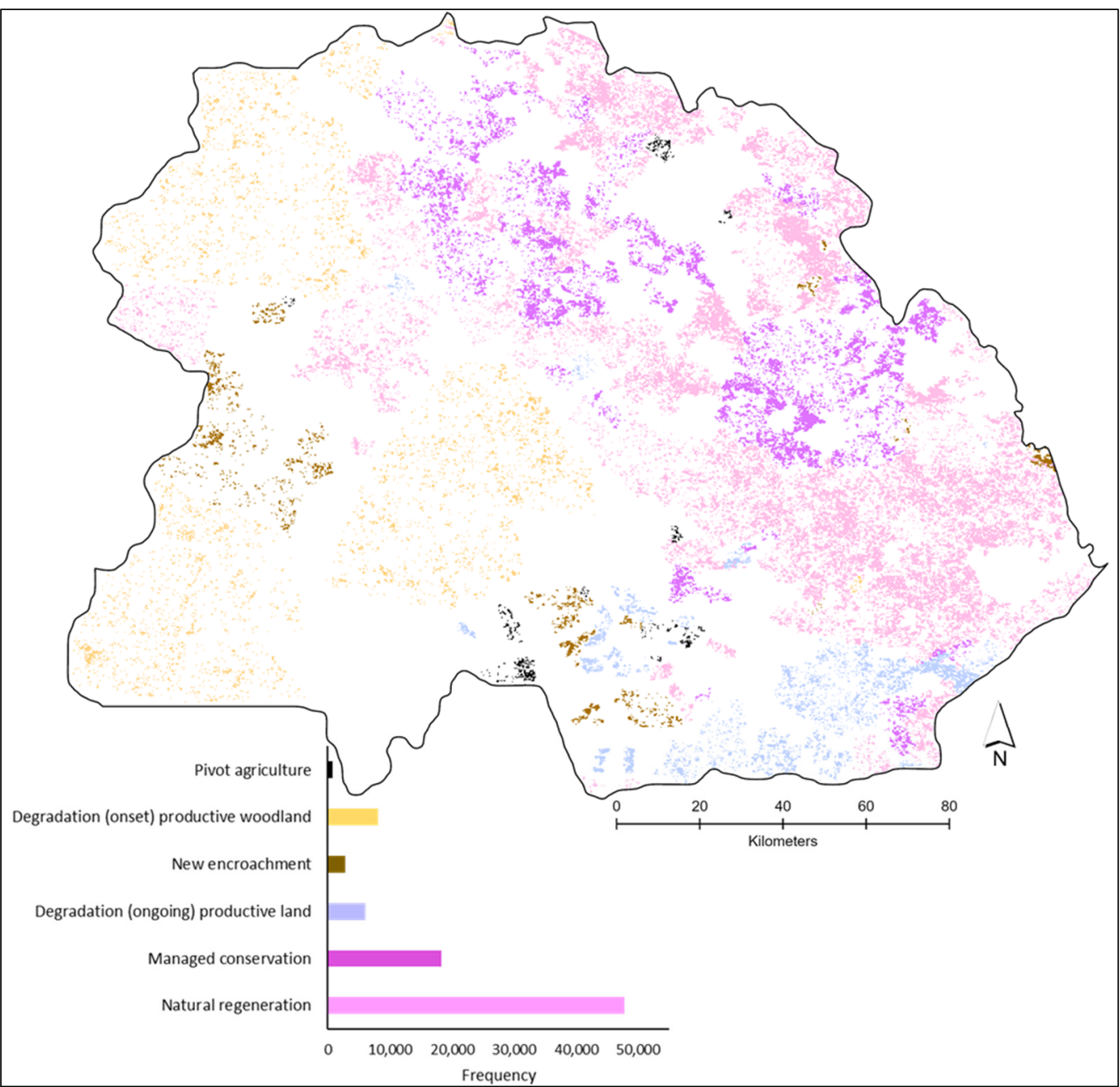

Figure 6. Distribution of land change dynamics. According to the scale in the map $1 \mathrm{~cm}$ equals $10 \mathrm{~km}$.

The most dominant land change with high greening trends was natural regeneration mainly driven by the mosaic subclasses. This pattern was more prominent in the east of Copperbelt where most of agricultural activities are focused. In case of degradation, the major land change dynamic was the onset of degradation in productive woodlands, followed by ongoing degradation on productive land largely due to shifting plots sub class. Both of the degradation classes contain the word 'productive' because they showed greening trends, in addition to browning trends, which meant that the land is still able to sustain miombo woodlands and crop cultivation with the possibility of high yields, provided that land reclamation measures are also carried out. In addition to existing shifting plots, few areas experienced clear cuts for new plots (new encroachment class). Pivot agriculture was mostly present in the southern district of Mpongwe, which is the 'grain basket' of Copperbelt. It was not a prominent land process in the study area since most of the crops are rainfed.

For illustration, Figure 7 shows monthly EVI time series for various land change sub classes for selected pixels. The development of the index signal shows the following patterns: where there are shifting plots involved; there is a pronounced seasonal cycle as opposed to woodland. For instance, Figure 7II displays a distinct shift of seasonality after woodland conversion. Furthermore, it is interesting to note the higher peaks attained after conversion (post 2015 in Figure 7II) indicating the productivity of land. In the case of forest reserves and plantations, some abrupt changes can be seen in the signal suggesting clear cuts and rapid regrowth (also visible on Landsat imagery). For mosaic areas the seasonality is not so well defined; nevertheless, higher peaks can be seen, which demonstrate productivity and recovery post disturbance (see discussion for more details). This is also 
evidenced in Figure 8 where a significant increasing trend in the annual peaking magnitude was observed.
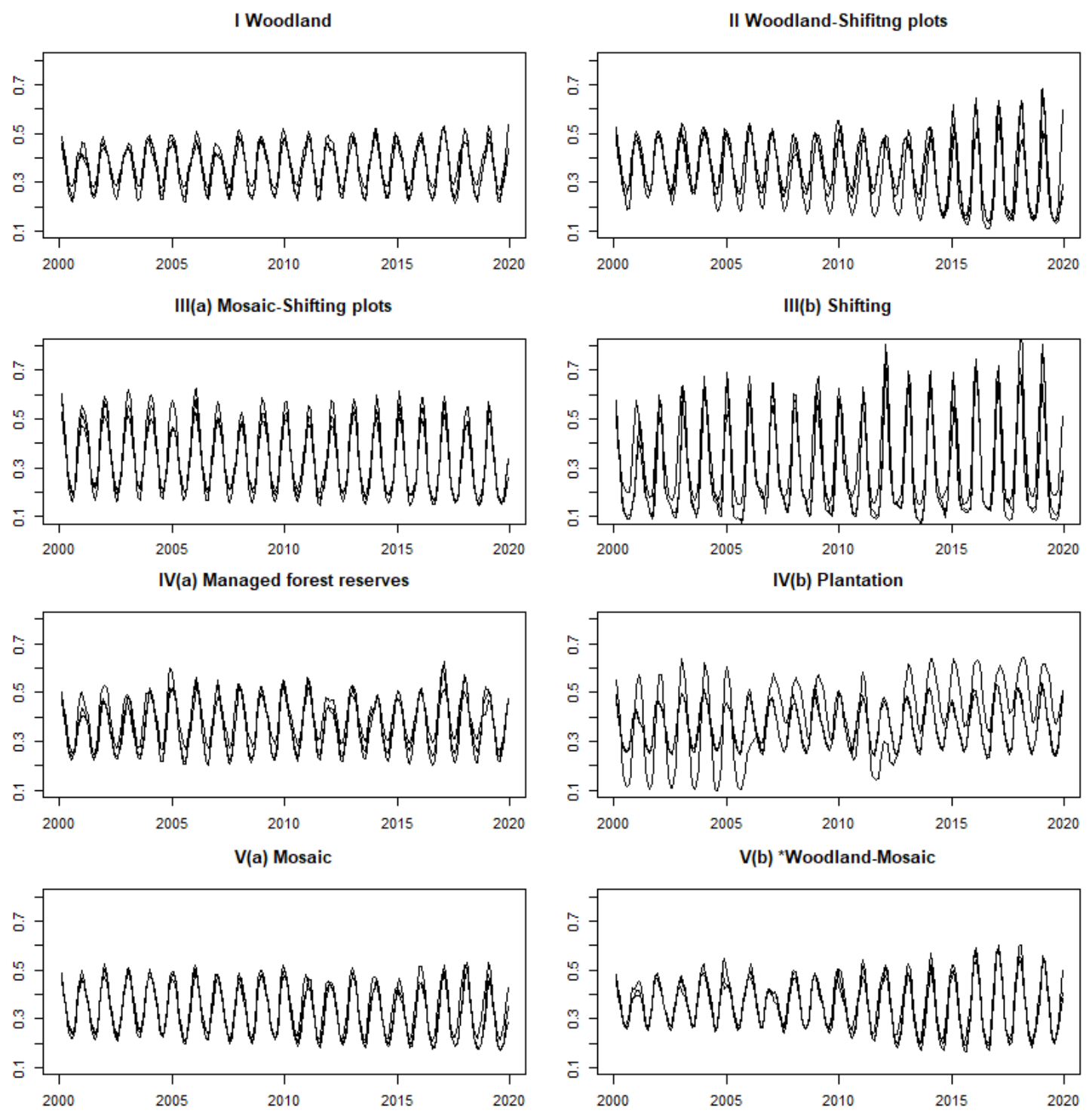

V(c) Shifting plots-Mosaic

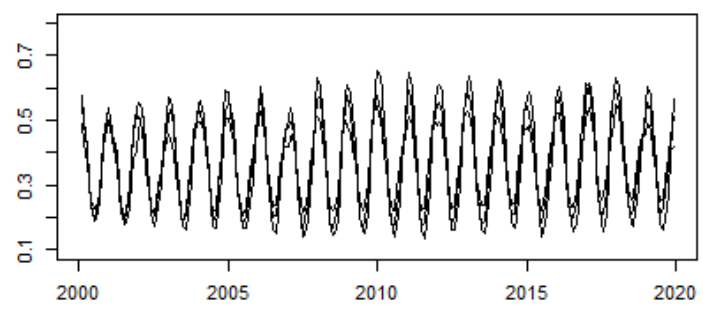

Figure 7. EVI Time series for various land change sub classes: I: Onset of degradation, II: New encroachment, III: Ongoing degradation, VI: Managed conservation, V: Natural regeneration. * Intermediate conversion to shifting plots. Each plot shows three time series. 

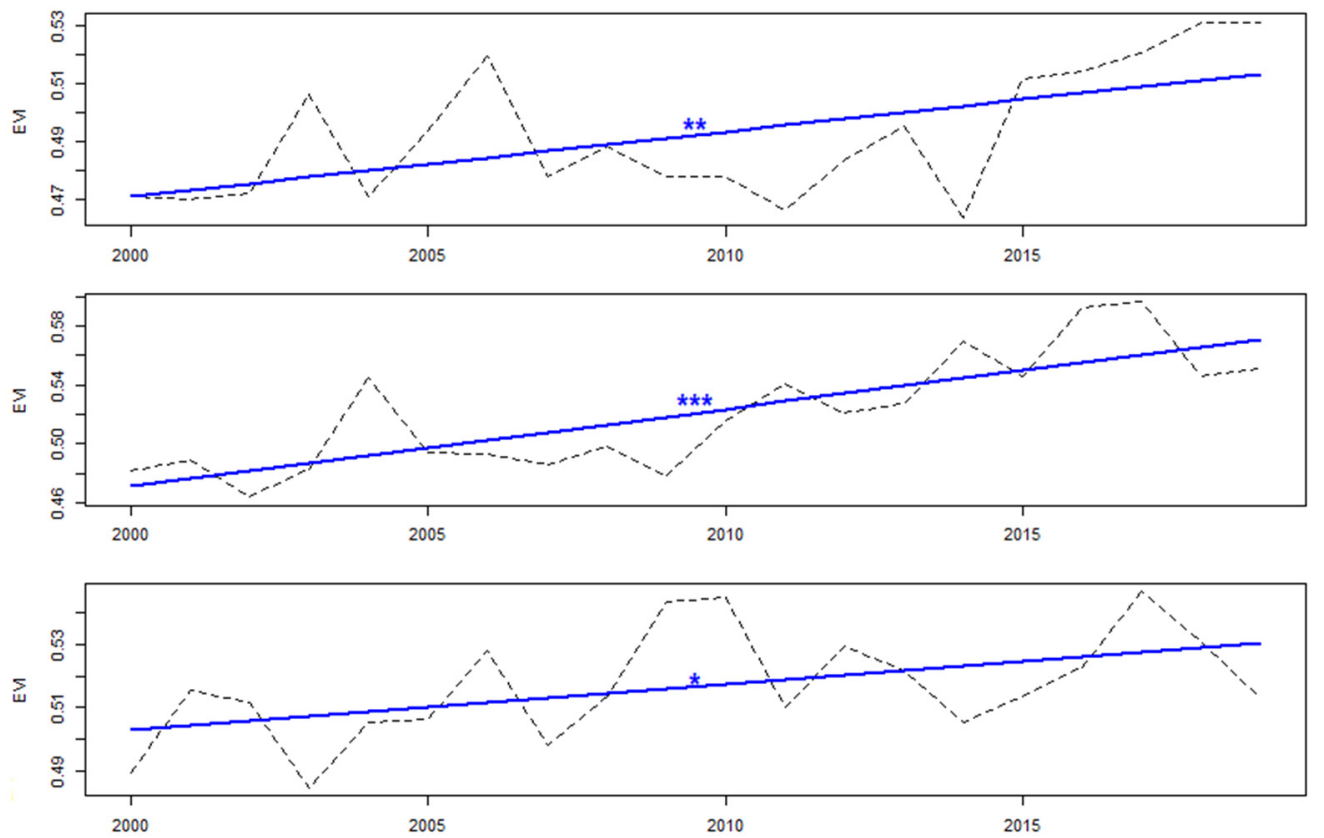

Figure 8. Trend (blue line) of annual peaking magnitude for mosaic areas. The symbol * shows the trend is significant, ${ }^{*}$ has $p$ value less than $0.05,{ }^{* *}$ has $p$ value less than 0.005 , and ${ }^{* * *}$ has $p$ value less than 0.000001 .

\section{Discussion}

This section deals with each major land dynamic by dividing them into three broad categories: (1) degradation, which includes onset of degradation on productive woodland, ongoing degradation on productive land, and new encroachment; (2) recovery, which includes natural regeneration; and (3) land management, which includes managed conservation. Pivot agriculture will not be discussed since, according to our results, it had a negligible role in driving long-term land change processes in Copperbelt. Nevertheless, given the changes in rainfall regimes and recurring droughts, irrigation might play a significant role in the near future.

Before proceeding with analyzing the land change processes, providing a statistical context to estimated trends is necessary. Remotely sensed time series hold immense potential for monitoring studies. However, statistical models, such as the one used in our study, applied to calculate trends, result in uncertainties, namely, Type I (false positive) and Type II errors (false negative). Type I errors can be easily propagated due to temporal autocorrelation, thus giving rise to trend patterns that might not depict any real change [49]. Unless there is an independent reference data set available, which is rarely the case with satellite time series, direct validation, and accuracy assessment of results is not possible. In such cases, indirect validation of the statistical output has to be carried out [50]. For instance, our study correlated the primary analyzed data with other data sets and products, which had either higher spatial resolution (Landsat EVI and NDMI), or higher accuracy (Global Forest Change data).

\subsection{Degradation}

One of the key factors in causing direct and indirect land degradation in Copperbelt is shifting and semi-permanent cultivation. According to Figure 9, areas with shifting cultivation showed a high pixel count with browning trend found for all three parameters. Small-scale farming is dominant in the study region where farmers usually cultivate less than 5 ha of land. Out of total land area of 3,132,829 ha, around 307,000 ha is arable, of which only 130,000 ha is under cultivation [51]. Block 'chitemene' is a widely practiced form of shifting cultivation in Copperbelt province. In Zambia, as a whole, agricultural land expansion is responsible for the loss of 25,000 ha of forested land per year [18]. Expansion 
of $1.29 \%$ of cropland into forests by small-scale farmers in Copperbelt was reported by the Rural Agricultural Livelihoods Survey [20] especially between 2010 and 2018. This was also evidenced in our results in the form of 'new encroachment', where new shifting plots appeared in intact woodlands west of the study site. Furthermore, according to the Global Forest Change data set, deforestation accelerated after 2010. Figure 10 shows that degradation post 2010 is responsible for major browning trends, especially in the categories woodland to shifting, mosaic to shifting, and mosaic.

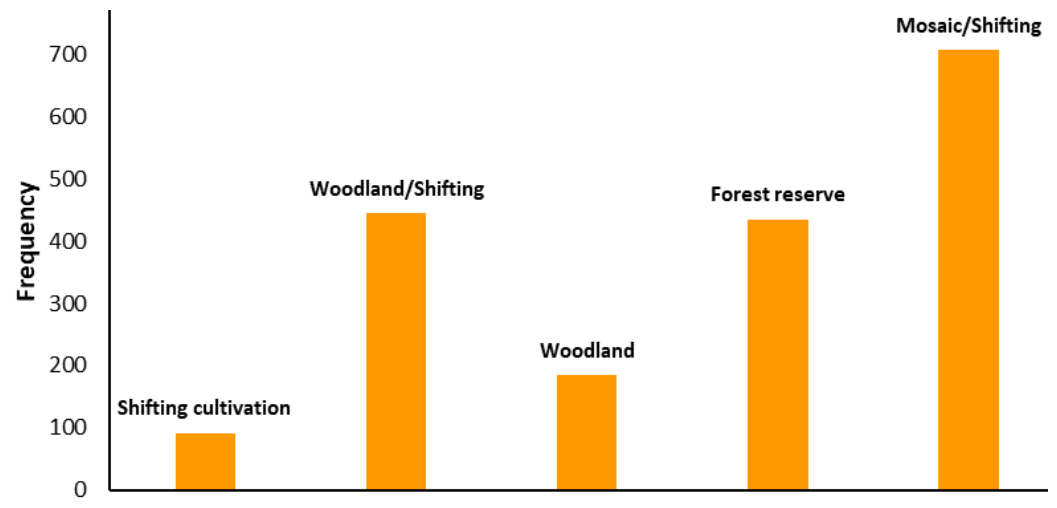

Figure 9. Browning trend for all three parameters for various land change dynamics.

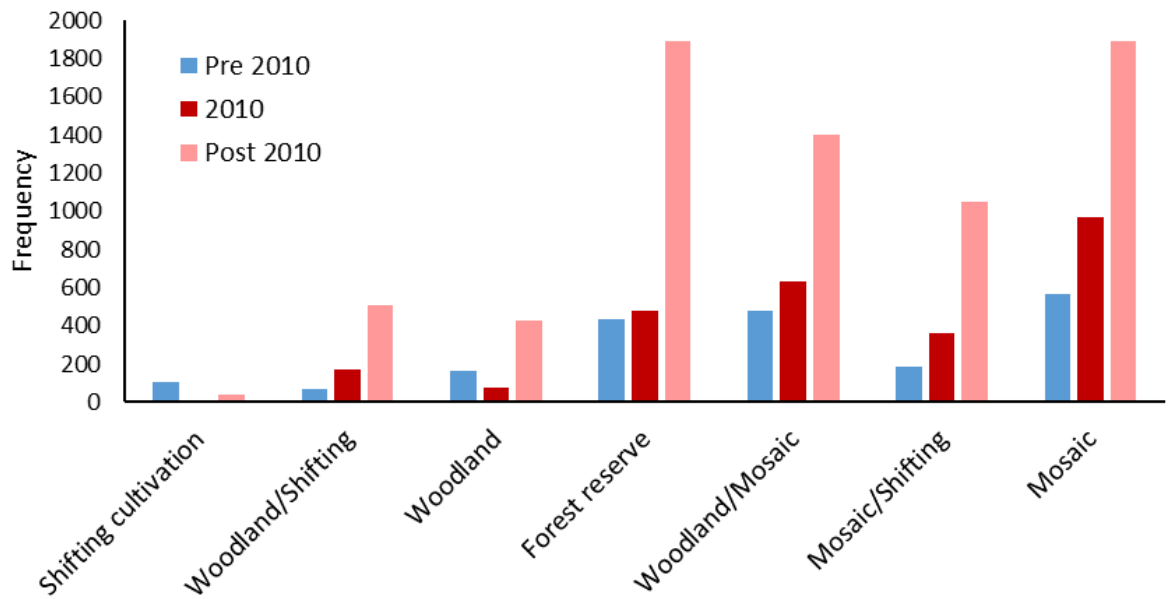

Figure 10. Land change dynamics against Global Forest Change deforestation data classified here as before 2010, in the year 2010, and after 2010.

The survey [20] also suggested that in addition to fulfilling subsistence needs, poor soil was a major factor for cropland expansion. Figure 11 shows negative trends of peaking magnitude on existing shifting plots and mosaic to shifting class. Our study observed dominant degradation on productive land in the east of Mpongwe. This could be due to transition from long-fallow to intensive short-fallow cultivation leading to soil nutrient exhaustion as observed in other parts of the miombo [52]. Under a likely scenario of rise in population, especially rural (small-scale farmers) population, (Figure 12), agricultural expansion must be expected as a strategy to compensate for declining soil fertility, which may eventually leave new forest areas vulnerable to deforestation.

Maize is one of the major food crops in Zambia and it is grown widely in southern Copperbelt. Maize yields have seen a rise (Figure 13) in Copperbelt. This is partly due to consistent expansion of area under maize in the region, especially from 2000 onwards. In addition, it is also due agricultural intensification in the form of increased application of synthetic nitrogen fertilizer in Zambia (Figure 13). Excessive use of fertilizers can exacerbate soil acidity of the Agro ecological zone III, where Copperbelt is situated. Adding to that is soil exhaustion caused by monocropping highly 'nutrient demanding' maize [16]. 
These factors subsequently lead to long term soil infertility and severe reduction in land productivity.
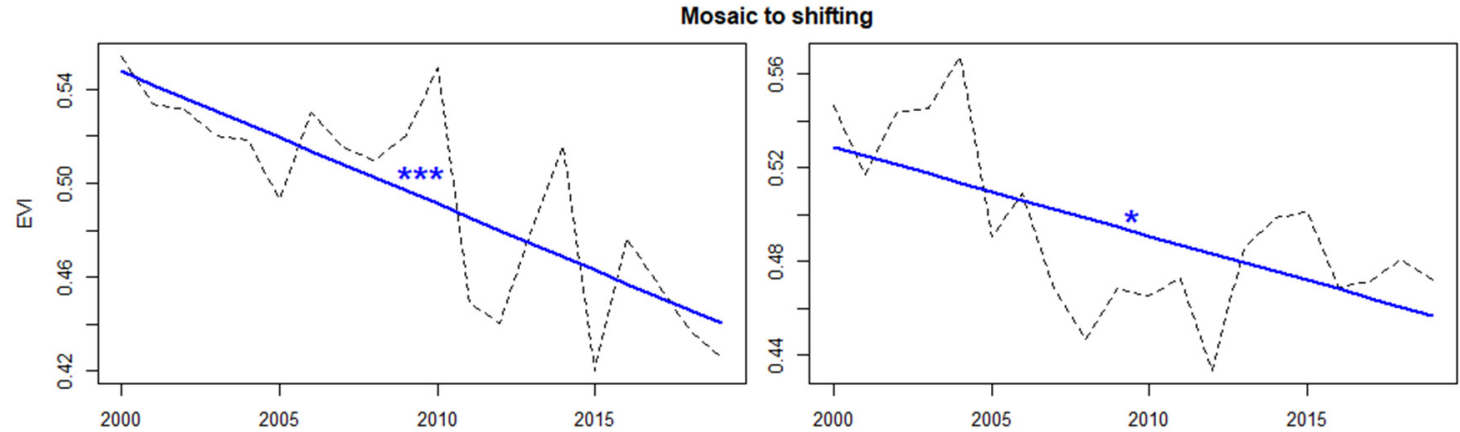

Shifting cultivation
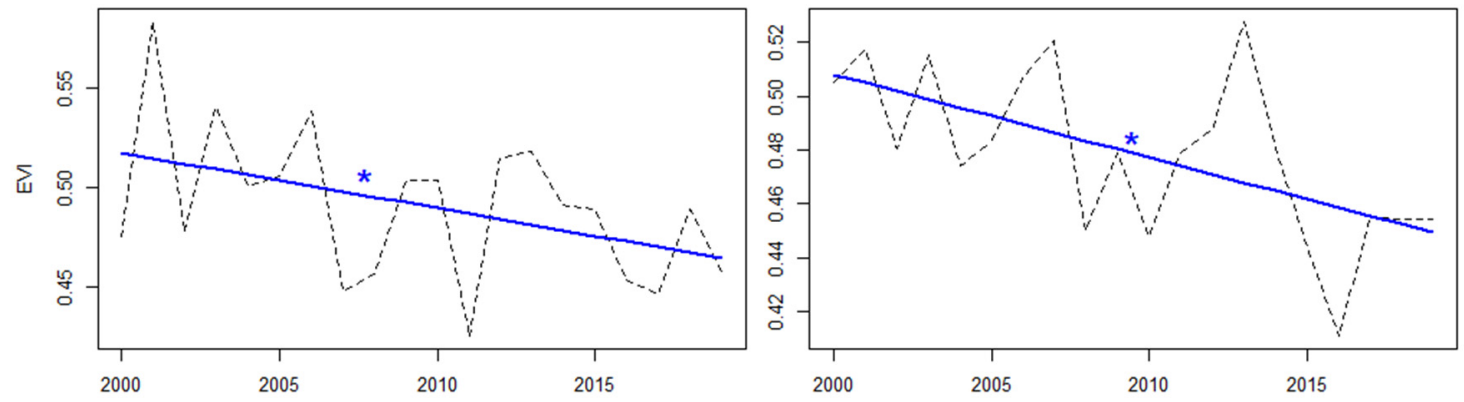

Figure 11. Trend (blue line) of annual peaking magnitude for mosaic to shifting (top) and shifting cultivation (bottom). The symbol * shows the trend is significant, ${ }^{*}$ has $p$ value less than 0.05 and *** has $p$ value less than 0.000001 . EVI range for $y$-axis is not constant for each plot.

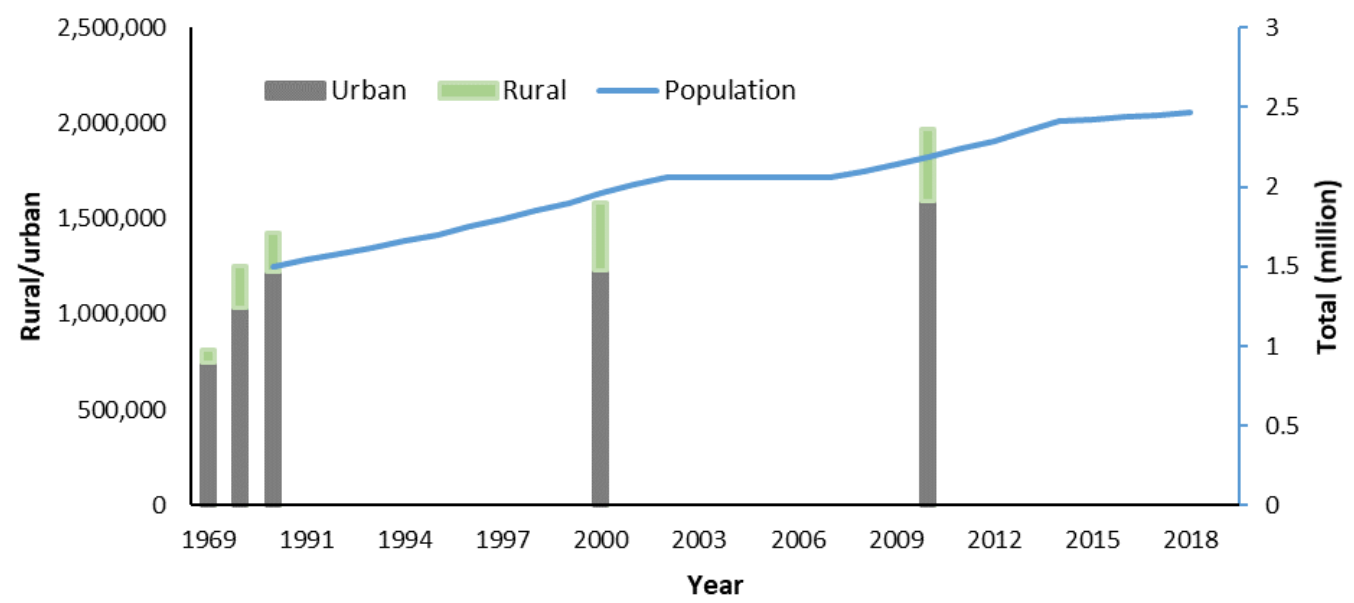

Figure 12. Rural, urban, and total population in Copperbelt. Data taken from Zambia Central Statistical Office.

Onset of degradation in productive woodland is closely associated with new encroachment; however, there were additional drivers responsible for browning trends represented in Figure 9. Copperbelt is one of the major hotspots for wood harvest (charcoal and fuel) in Zambia, which contributes around 20\% (charcoal) and $8 \%$ (fuelwood) to degradation processes. This province is dominated by northern wet miombo species, such as high density Brachystegia spiciformis, Isoberlinia angolensis, and Julbernadia paniculata, which are highly suitable for charcoal [18] and other forms of energy application. The authors of [53] attributed 18,850 ha of deforestation in Copperbelt to charcoal production for the year 1995. Due to uncertainties in the mining sector, and drought induced poor crop harvest, most local community members are turning to charcoal as an additional source of income. 


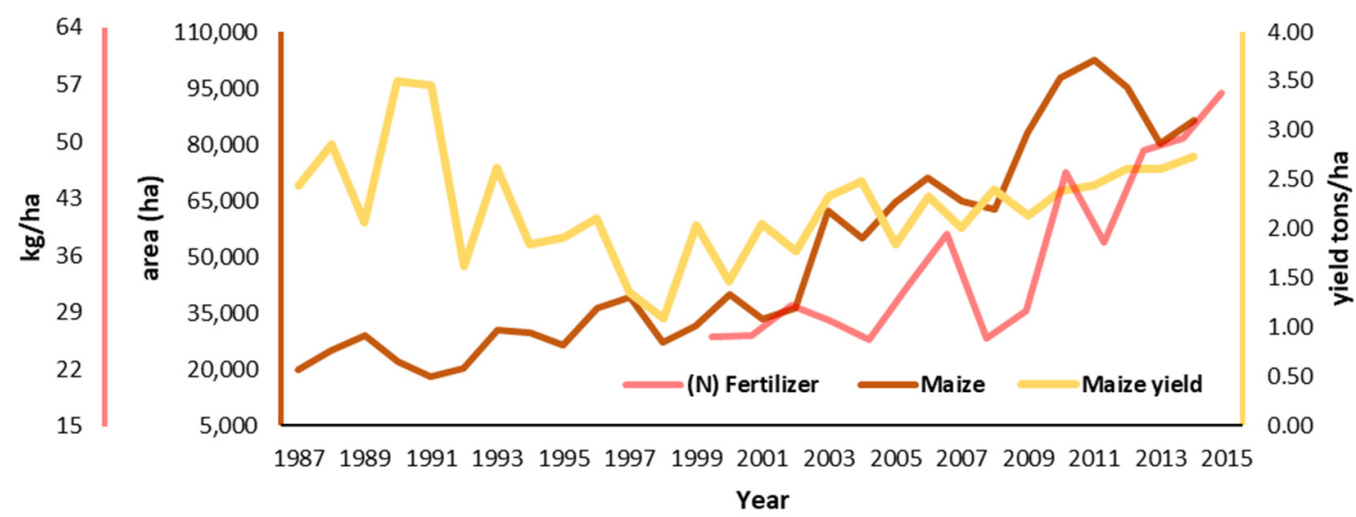

Figure 13. Area under maize, maize yield (Copperbelt) and fertilizer use (Zambia). Data taken from Zambia Central Statistical Office.

About $16 \%$ of households in Copperbelt are involved with charcoal use [54]. The authors in [55] reported that charcoal contributed 37\% to household income in the Copperbelt province and it was the main processed forest product used for subsistence and cash income in many parts of the province [56]. It is interesting to note that some proportion of wood being used for fuel or charcoal comes from preparing cleared chitemene fields. However, where there is scarcity of deadwood, then live trees are selectively harvested rather than being clear cut, leading to damaged forest canopy. This seems to be the case in our study where browning trends for onset of degradation in productive woodland were strongly observed in Lufwanyama and west of the Mpongwe district. An indirect driver of forest degradation is electricity shortage in Zambia. An unreliable supply of electricity has caused heavy dependence on fuelwood and charcoal especially in rural towns of Copperbelt [57]. A study via key informant interviews in Copperbelt, Lusaka, and Southern province revealed that load shedding and high charcoal demand had a contribution of $46 \%$ to increased charcoal production [58].

\subsection{Recovery}

Natural regeneration, which primarily involved the mosaic class, was responsible for most of the greening trends. In fact, the mosaic class showed a high pixel count with greening trend for all three parameters (Figure 14). It has been suggested that for Miombo woodlands, mosaic restoration can play an important role in particular for small land holder farmers, charcoal producers, and in areas with population density between 10 and $100 \mathrm{~km}^{2}$. It is so since these areas have relatively higher population and present a classic case of heterogeneity in land use [21]. According to our mapped land change dynamics, natural regeneration was observed strongly in districts with population density between 10 and $100 \mathrm{~km}^{2}$; however, it was also observed in districts with more than $100 \mathrm{~km}^{2}$ population density such as Kitwe (Figure 15).

Formation of mosaic landscapes is closely associated with the chitemene cultivation process. To prepare the fields, approximately the size of $1 \mathrm{ha}$, trees are cut at about $1 \mathrm{~m}$ height (coppicing) from the ground at the beginning of the dry season. The cut branches are placed in the inner field area, and dried and burnt. Regeneration of miombo woodland has been widely reported, resulting from various reasons: stumps and root suckers post coppicing aids in fast regrowth; vertical and horizontal root systems support rejuvenation; and oblige cuts (as opposed to horizontal cuts) prevent water collection and rotting at the cut site; and increased exposure to sunlight after canopy removal favors high germination and recruitment of old stunted seedlings [8]. However, studies in other parts of the Miombo have shown regeneration may not recover to the original density and floristic composition [59] depending on the frequency and intensity of utilization or disturbance.

Our results showed strong recovery patterns due to natural regeneration in the south east of the study site, namely, the Masaiti district, this was also observed by [8]. These areas are in the phase of fresh regrowth, which is why they were classified as mosaic. 
Natural regeneration is a common phenomenon of the miombo woodland. This is because miombo species are equipped with diverse regeneration modes (true seedling, seedling sprout, root sucker, coppice, and water sprout) that provide for easy recovery on cessation of the disturbance [60]. Opening of the canopy either through slash and burn agriculture or charcoal production stimulates the development of these forms of regeneration as the temperature and light intensity increase [61]. Exposure of stumps, seedlings, and other regeneration modes to sunlight enhances their regeneration effectiveness for most woodland species [62]. It is likely that regrowth stands will enter another cycle of shifting cultivation after reaching maturity. If, in the next 20 years or so, the miombo regenerate in the East, then it could prevent overexploitation of intact woodland in the West of Copperbelt.

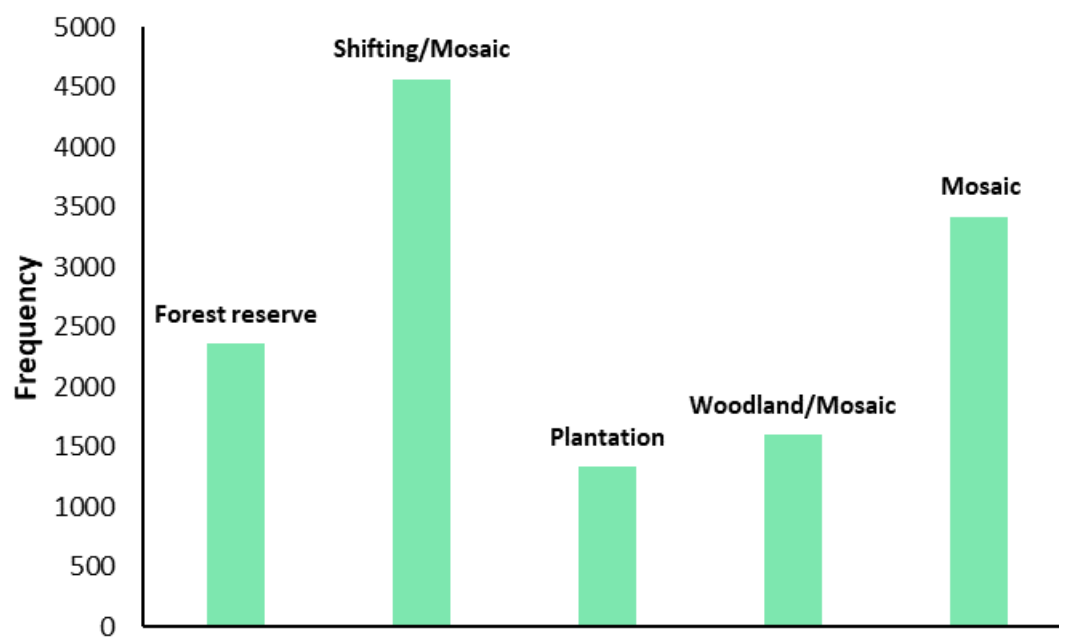

Figure 14. Greening trend for all three parameters for various land change dynamics.

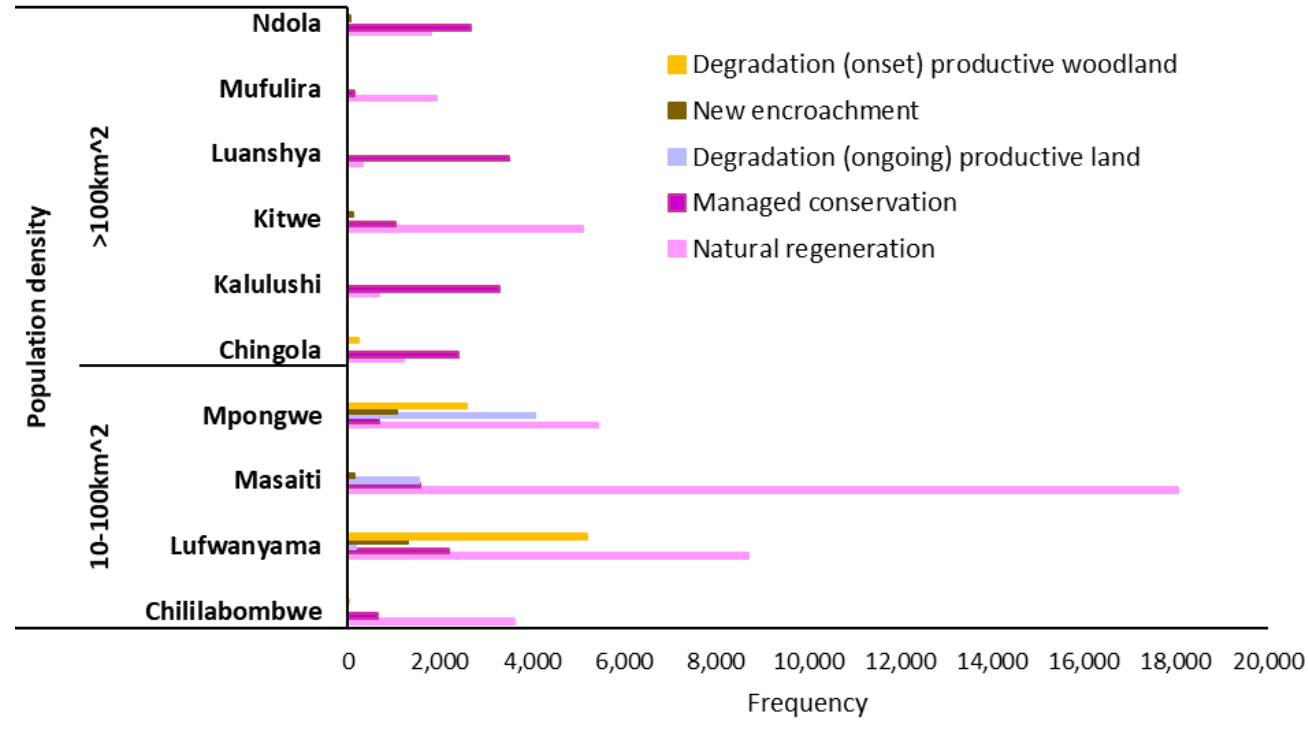

Figure 15. Land change dynamics represented according to districts of Copperbelt.

\subsection{Land Management}

Of all the forest plantations in Zambia, $80 \%$ are established in Copperbelt [63]. In the current study, managed conservation was rather pronounced in the districts in the central north and the east of the study region (Figure 15). According to [64], pine and eucalyptus plantations covering an area of 50,000 ha exist in the districts of Ndola, Chingola, Lufwanyama, Kalulushi, Mufulira, and Kitwe. This could be due to the high demand of structural timber by the mining industry. Forest revenue generated from Copperbelt has 
one of the highest contributions to national forest revenue in the form of timber and wood fuel [65]. We observed some clear cuts in forest reserves and they showed browning patterns for all trend parameters (Figure 9). The authors in [66] highlighted that customary lands are prone to agricultural expansion, while state land with forest reserves are cleared to supply charcoal and timber. Some of the clearing activities could be part of managed plantations specifically to supply wood, such as in districts of Ndola and Kalulushi (Figure 16). Some of these could be related to illegal harvest; however, it was difficult to differentiate that in our study, which is why we did not categorize this as degradation.

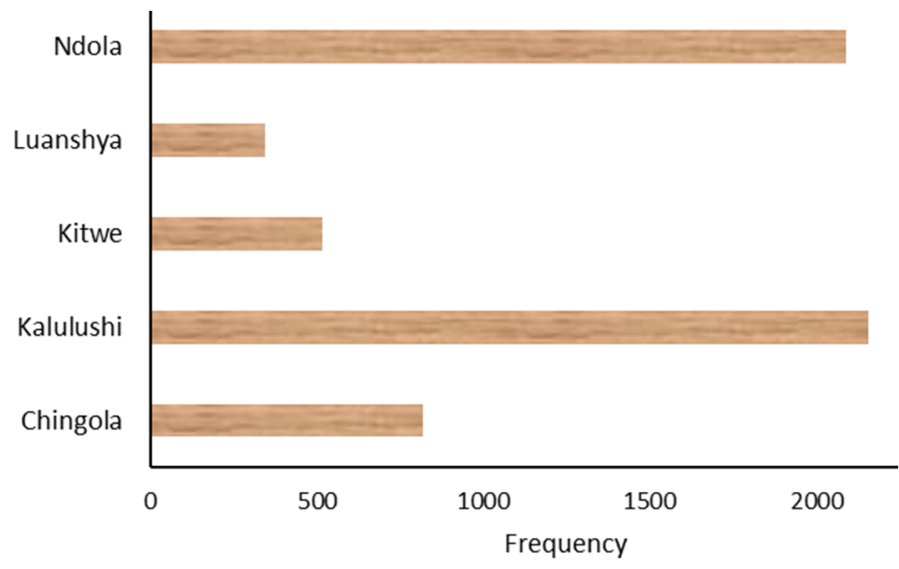

Figure 16. Frequency of clear cuts in forest reserve category in different districts.

Under the category managed conservation, we mapped areas with restorative plantations. These sites represent assisted natural generation in small hold farms, where sustainable harvest of miombo is promoted. Such plantations showed overall greening patterns (Figure 14) predominantly in Luanshya, and additionally in Masaiti, east Mpongwe, and Ndola. The restorative plantations, mapped in our study, have been established over an area of 5144 ha. It could be inferred from our findings that these plantations might reverse deforestation trends and help in establishing sustainable land management. However, it is unclear as to whether these practices can preserve miombo woodlands to the extent that they provide ecosystem services comparable to those of pre-disturbance levels.

\section{Conclusions}

Our study combines statistical analysis of remotely sensed time series and a rulebased change type assignment. It provides an overview of land change dynamics in the Copperbelt region of Zambia within a local context, which are directly linked with processes of land degradation. Our place-based interpretation is based on diverse data sources, including Landsat imagery and derived information products (e.g., Global Forest Change Hansen deforestation data), auxiliary geospatial data, and high-resolution Bing map and Google Earth imagery and administrative data. The discussion relied on expert interpretation and knowledge.

We make the following inferences from our study: (a) mosaic landscapes are dominant in the study site and therefore hold potential for ecological restoration; (b) despite greening trends being dominant, degradation still poses huge concern since it is giving rise to long term browning trends over intact woodlands; (c) although forests/plantations under managed conservation showed positive trends; however, they are highly susceptible to charcoal harvest; and (d) future intensified agriculture in the form of pivot and smallholder irrigation due to decreased land productivity on existing agricultural areas.

It is suggested to use annually aggregated time series data in place of monthly seasonal series where shifting cultivation plots with varying spatial footprint are prevalent. Regarding the mapping procedure we conclude that mapping land change dynamics in a local context can only be partially automated. We suggest that place-based assessments may be conducted in two phases: an automated phase based on parameters derived from 
time series data, and a semi-automatic interpretation phase that makes use of expert knowledge and auxiliary data. This results in two sets of products: one objective and purely statistically based, and one representing a systematic interpretation to aid mitigation of land degradation and evaluation of restoration measures.

Author Contributions: Conceptualization, S.M., T.U. and A.R.; methodology, S.M., T.U. and A.R.; validation, S.S.; formal analysis, S.M.; investigation, S.M.; data curation, S.M.; writing—original draft preparation, S.M.; writing-review and editing, S.M., T.U., A.R. and S.S.; supervision, T.U. and A.R. All authors have read and agreed to the published version of the manuscript.

Funding: The publication of this manuscript was supported by the Open Access Publication Fund of Trier University.

Data Availability Statement: The open source dataset used for the main analysis in this study was MODIS derived vegetation index. It can be found at https://1pdaacsvc.cr.usgs.gov/appeears/, accessed on 15 December 2021.

Acknowledgments: The authors are grateful to all open-source data sets (MODIS EVI, Global Forest Cover Change, WeForest plantation databank, and ILUA project) used for analysis in this study. We thank the anonymous reviewers for their helpful remarks and feedback.

Conflicts of Interest: The authors declare no conflict of interest.

\section{References}

1. Vogt, J.V.; Safriel, U.; von Maltitz, G.; Sokona, Y.; Zougmore, R.; Bastin, G.; Hill, J. Monitoring and Assessment of Land Degradation and Desertification: Towards New Conceptual and Integrated Approaches. Land Degrad. Dev. 2011, 22, 150-165. [CrossRef]

2. Reynolds, J.F.; Maestre, F.T.; Kemp, P.R.; Stafford-Smith, D.M.; Lambin, E. Natural and Human Dimensions of Land Degradation in Drylands: Causes and Consequences. In Terrestrial Ecosystems in a Changing World; Springer: Berlin, Germany, 2007 ; pp. $247-257$.

3. International Food Policy Research Institute. Global Food Policy Report; International Food Policy Research Institute: Washington, DC, USA, 2013.

4. Adeel, Z. Ecosystems and Human Well-Being: Desertification Synthesis: A Report of the Millennium Ecosystem Assessment; World Resources Institute: Washington, DC, USA, 2005.

5. Geist, H.J.; Lambin, E.F. Dynamic Causal Patterns of Desertification. Bioscience 2004, 54, 817-829. [CrossRef]

6. Schultz, M.; Shapiro, A.; Clevers, J.G.P.W.; Beech, C.; Herold, M. Forest Cover and Vegetation Degradation Detection in the Kavango Zambezi Transfrontier Conservation Area Using BFAST Monitor. Remote Sens. 2018, 10, 1850. [CrossRef]

7. Veron, S.R.; Paruelo, J.M.; Oesterheld, M. Assessing Desertification. J. Arid. Environ. 2006, 66, 751-763. [CrossRef]

8. Syampungani, S.; Chirwa, P.W.; Akinnifesi, F.K.; Ajayi, O.C. The Potential of Using Agroforestry as a Win-Win Solution to Climate Change Mitigation and Adaptation and Meeting Food Security Challenges in Southern Africa. Agric. J. 2010, 5, 80-88. [CrossRef]

9. Munyati, C. Wetland Change Detection on the Kafue Flats, Zambia, by Classification of a Multitemporal Remote Sensing Image Dataset. Int. J. Remote Sens. 2000, 21, 1787-1806. [CrossRef]

10. Petit, C.; Scudder, T.; Lambin, E. Quantifying Processes of Land-Cover Change by Remote Sensing: Resettlement and Rapid Land-Cover Changes in South-Eastern Zambia. Int. J. Remote Sens. 2001, 22, 3435-3456. [CrossRef]

11. Simwanda, M.; Murayama, Y. Integrating Geospatial Techniques for Urban Land Use Classification in the Developing Sub-Saharan African City of Lusaka, Zambia. ISPRS Int. J. Geo-Inf. 2017, 6, 102. [CrossRef]

12. Chomba, B.M.; Tembo, O.; Mutandi, K.; Mtongo, C.S.; Makano, A. Drivers of Deforestation, Identification of Threatened Forests and Forest Co-Benefits Other than Carbon from REDD+ Implementation in Zambia. In A Consultancy Report Prepared for the Forestry Department and the Food and Agriculture Organization of the United Nations under the National UN-REDD Programme; Ministry of Lands, Natural Resources and Environmental Protection: Lusaka, Zambia, 2012.

13. Mukosha, J.; Siampale, A. Integrated Land Use Assessment (ILUA): Zambia, 2005-2008; Zambia Forestry Department, Ministry of Tourism, Environment and Natural: Lusaka, Zambia, 2008.

14. Trapnell, C.G.; Clothier, T.N. The Soils, Vegetation and Agricultural Systems of North-Western Rhodesia; Government Printers: Lusaka, Zambia, 1937.

15. Environment Council of Zambia. Zambia Environment Outlook Report 3; Environment Council of Zambia: Lusaka, Zambia, 2008.

16. Conservation Farming Unit. Conservation Farming in Zambia. Conservation Farming Hand Book for Hoe Farmers in Agro Ecological Region III-The Basics; Conservation Farming Unit: Lusaka, Zambia, 2003.

17. Mason-Case, S. Legal Preparedness for REDD+ in Zambia: Country Study. In Report Prepared by the International Development Law Organisation (IDLO) with Support from the Food and Agriculture Organisation of the United Nations (FAO) and the UN-REDD Programme; International Development Law Organisation: Rome, Italy, 2011.

18. Vinya, R.; Syampungani, S.; Kasumu, E.C.; Monde, C.; Kasubika, R. Preliminary Study on the Drivers of Deforestation and Potential for REDD+ in Zambia; FAO/Zambian Ministry of Lands and Natural Resources: Lusaka, Zambia, 2011. 
19. Oksanen, T.; Mersmann, C. Forests in Poverty Reduction Strategies: An Assessment of PRSP Processes in Sub-Saharan Africa. For. Poverty Reduct. Strateg. Capturing Potential EFI Proc. 2003, 47, 121-158.

20. Chapoto, A.; Zulu-Mbata, O.; Beaver, M.; Chisanga, B.; Kabwe, S.; Kuteya, A.N.; Munsaka, E.; Namonje-Kapembwa, T.; Tembo, S.; Sitko, N. Rural Agricultural Livelihoods Survey: 2015 Survey Report; Indaba Agricultural Policy Research Institute (IAPRI): Lusaka, Zambia, 2016.

21. Henry, M.; Maniatis, D.; Gitz, V.; Huberman, D.; Valentini, R. Implementation of REDD+ in Sub-Saharan Africa: State of Knowledge, Challenges and Opportunities. Environ. Dev. Econ. 2011, 16, 381-404. [CrossRef]

22. Ministry of Tourism, Environment and Natural Resources. Zambia National Action Program for Combating Desertification and Mitigating Serious Effects of Drought; Ministry of Tourism, Environment and Natural Resources: Lusaka, Zambia, 2002.

23. Chidumayo, E.N. Development of Reference Emission Levels for Zambia. In Report Prepared for the UN Food and Agriculture Organisation (FAO) and UN Reducing Emissions from Deforestation and Forest Degradation (UN REDD); Makeni Savanna Research Project: Lusaka, Zambia, 2012.

24. Kalaba, F.K. Barriers to Policy Implementation and Implications for Zambia's Forest Ecosystems. For. Policy Econ. 2016, 69, 40-44. [CrossRef]

25. Tucker, C.J. Red and Photographic Infrared Linear Combinations for Monitoring Vegetation. Remote Sens. Environ. 1979, 8, 127-150. [CrossRef]

26. Graetz, R.D. Empirical and Practical Approaches to Land Surface Characterisation and Change Detection. In The Use of Remote Sensing for Land Degradation and Desertification Monitoring in the Mediterranean Basin; European Commission: Brussels, Belgium, 1996; pp. 9-22.

27. Hill, J.; Hostert, P.; Röder, A. Long-Term Observation of Mediterranean Ecosystems with Satellite Remote Sensing. In Recent Dynamics of the Mediterranean Vegetation and Landscape; John Wiley \& Sons Ltd: Chichester, UK, 2004; pp. 33-43.

28. Gobron, N.; Verstraete, M.M.; Pinty, B.; Taberner, M.; Aussedat, O. Potential of Long Time Series of FAPAR Products for Assessing and Monitoring Land Surface Changes: Examples in Europe and the Sahel. In Recent Advances in Remote Sensing and Geoinformation Processing for Land Degradation Assessment; CRC Press: London, UK, 2009; pp. 109-122. ISBN 042920681X.

29. Cho, M.A.; Ramoelo, A. Optimal Dates for Assessing Long-Term Changes in Tree-Cover in the Semi-Arid Biomes of South Africa Using MODIS NDVI Time Series (2001-2018). Int. J. Appl. Earth Obs. Geoinf. 2019, 81, 27-36. [CrossRef]

30. Leroux, L.; Bégué, A.; Seen, D.L.; Jolivot, A.; Kayitakire, F. Driving Forces of Recent Vegetation Changes in the Sahel: Lessons Learned from Regional and Local Level Analyses. Remote Sens. Environ. 2017, 191, 38-54. [CrossRef]

31. Schneibel, A.; Stellmes, M.; Röder, A.; Frantz, D.; Kowalski, B.; Haß, E.; Hill, J. Assessment of Spatio-Temporal Changes of Smallholder Cultivation Patterns in the Angolan Miombo Belt Using Segmentation of Landsat Time Series. Remote Sens. Environ. 2017, 195, 118-129. [CrossRef]

32. Phiri, D.; Morgenroth, J.; Xu, C. Long-Term Land Cover Change in Zambia: An Assessment of Driving Factors. Sci. Total Environ. 2019, 697, 134206. [CrossRef]

33. Fiorillo, E.; Maselli, F.; Tarchiani, V.; Vignaroli, P. Analysis of Land Degradation Processes on a Tiger Bush Plateau in South West Niger Using MODIS and LANDSAT TM/ETM+ Data. Int. J. Appl. Earth Obs. Geoinf. 2017, 62, 56-68. [CrossRef]

34. Higginbottom, T.P.; Symeonakis, E. Identifying Ecosystem Function Shifts in Africa Using Breakpoint Analysis of Long-Term NDVI and RUE Data. Remote Sens. 2020, 12, 1894. [CrossRef]

35. Zimba, H.; Kawawa, B.; Chabala, A.; Phiri, W.; Selsam, P.; Meinhardt, M.; Nyambe, I. Assessment of Trends in Inundation Extent in the Barotse Floodplain, Upper Zambezi River Basin: A Remote Sensing-Based Approach. J. Hydrol. Reg. Stud. 2018, 15, 149-170. [CrossRef]

36. Munawar, S.; Udelhoven, T. Land Change Syndromes Identification in Temperate Forests of Hindukush Himalaya Karakorum (HHK) Mountain Ranges. Int. J. Remote Sens. 2020, 41, 7735-7756. [CrossRef]

37. Huete, A.; Didan, K.; Miura, T.; Rodriguez, E.P.; Gao, X.; Ferreira, L.G. Overview of the Radiometric and Biophysical Performance of the MODIS Vegetation Indices. Remote Sens. Environ. 2002, 83, 195-213. [CrossRef]

38. Team, A. Application for Extracting and Exploring Analysis Ready Samples (AppEEARS); Version 2.49; NASA EOSDIS Land Processes Distributed Active Archive Center (LP DAAC), USGS/Earth Resources Observation and Science (EROS) Center: Sioux Falls, SD, USA, 2020.

39. Atzberger, C.; Eilers, P.H.C. A Time Series for Monitoring Vegetation Activity and Phenology at 10-Daily Time Steps Covering Large Parts of South America. Int. J. Digit. Earth 2011, 4, 365-386. [CrossRef]

40. Mattiuzzi, M.; Lobo, A. Acquisition and Processing of MODIS Products; R Package: Vienna, Austria, 2012.

41. Ollinger, S.V. Sources of Variability in Canopy Reflectance and the Convergent Properties of Plants. New Phytol. 2011, 189, 375-394. [CrossRef]

42. Verbesselt, J.; Hyndman, R.; Zeileis, A.; Culvenor, D. Phenological Change Detection While Accounting for Abrupt and Gradual Trends in Satellite Image Time Series. Remote Sens. Environ. 2010, 114, 2970-2980. [CrossRef]

43. Tateishi, R.; Ebata, M. Analysis of Phenological Change Patterns Using 1982-2000 Advanced Very High Resolution Radiometer (AVHRR) Data. Int. J. Remote Sens. 2004, 25, 2287-2300. [CrossRef]

44. Zeileis, A.; Kleiber, C.; Krämer, W.; Hornik, K. Testing and Dating of Structural Changes in Practice. Comput. Stat. Data Anal. 2003, 44, 109-123. [CrossRef]

45. R Core TEAM. R: A Language and Environment for Statistical Computing; R Foundation for Statistical Computing: Vienna, Austria, 2009. 
46. Forkel, M.; Carvalhais, N.; Verbesselt, J.; Mahecha, M.D.; Neigh, C.S.R.; Reichstein, M. Trend Change Detection in NDVI Time Series: Effects of Inter-Annual Variability and Methodology. Remote Sens. 2013, 5, 2113-2144. [CrossRef]

47. Hansen, M.C.; Potapov, P.V.; Moore, R.; Hancher, M.; Turubanova, S.A.; Tyukavina, A.; Thau, D.; Stehman, S.V.; Goetz, S.J.; Loveland, T.R. High-Resolution Global Maps of 21st-Century Forest Cover Change. Science 2013, 342, 850-853. [CrossRef]

48. OpenStreetMap contributors Copyright and License. Available online: https://www.openstreetmap.org/copyright (accessed on 3 January 2022)

49. Ives, A.R.; Zhu, L.; Wang, F.; Zhu, J.; Morrow, C.J.; Radeloff, V.C. Statistical Inference for Trends in Spatiotemporal Data. Remote Sens. Environ. 2021, 266, 112678. [CrossRef]

50. Mayr, S.; Kuenzer, C.; Gessner, U.; Klein, I.; Rutzinger, M. Validation of Earth Observation Time-Series: A Review for Large-Area and Temporally Dense Land Surface Products. Remote Sens. 2019, 11, 2616. [CrossRef]

51. Copperbelt Provincial Administration Agriculture Investment Opportunities. Available online: https://www.cbt.gov.zm/?page_ $\mathrm{id}=4539$ (accessed on 9 December 2021).

52. Kwesiga, F.; Franzel, S.; Matongoya, P.; Ajayi, O.; Phiri, D.; Katanga, R.; Kuntashula, E.; Place, F.; Chira, T. Improved Fallows in Eastern Zambia: History, Farmer Practice and Impacts; Successes in African Agriculture Conference Background Paper No.12 and Environment and Production Technology Division Working Paper, 108; International Food Policy Research Institute: Washington, DC, USA, 2003.

53. Zambia Forestry Action Plan. Zambia Forestry Action Plan 1997-2015; Ministry of Environment and Natural Resoucres, Ed.; Forestry Department: Lusaka, Zambia, 1997.

54. Mulenga, B.; Nkonde, C.; Ngoma, H. Does Customary Land Tenure System Encourage Local Forestry Management in Zambia? A Focus on Wood Fuel; Indaba Agricultural Policy Research Institute: Lusaka, Zambia, 2015.

55. Kazungu, M.; Zhunusova, E.; Yang, A.L.; Kabwe, G.; Gumbo, D.J.; Günter, S. Forest Use Strategies and Their Determinants among Rural Households in the Miombo Woodlands of the Copperbelt Province, Zambia. For. Policy Econ. 2020, 111, 102078. [CrossRef]

56. Handavu, F.; Chirwa, P.W.C.; Syampungani, S. Socio-Economic Factors Influencing Land-Use and Land-Cover Changes in the Miombo Woodlands of the Copperbelt Province in Zambia. For. Policy Econ. 2019, 100, 75-94. [CrossRef]

57. Chidumayo, E. Charcoal Potential in Southern Africa (CHAPOSA): Final Report for Zambia; Stockholm Environment Institute: Lusaka, Zambia, 2002.

58. Dlamini, C.; Moombe, B.; Syampungani, S.; Samboko, P.C. Load Shedding and Charcoal Use in Zambia: What Are the Implications on Forest Resources. In Policy Brief; Working Paper 109; Indaba Agricultural Policy Research Institute: Lusaka, Zambia, 2016.

59. Schneibel, A.; Stellmes, M.; Röder, A.; Finckh, M.; Revermann, R.; Frantz, D.; Hill, J. Evaluating the Trade-off between Food and Timber Resulting from the Conversion of Miombo Forests to Agricultural Land in Angola Using Multi-Temporal Landsat Data. Sci. Total Environ. 2016, 548, 390-401. [CrossRef] [PubMed]

60. Syampungani, S.; Chirwa, P.W.; Geldenhuys, C.J.; Handavu, F.; Chishaleshale, M.; Rija, A.A.; Mbanze, A.A.; Ribeiro, N.S. Managing Miombo: Ecological and Silvicultural Options for Sustainable Socio-Economic Benefits. In Miombo Woodlands in a Changing Environment: Securing the Resilience and Sustainability of People and Woodlands; Springer: Cham, Switzerland, 2020; pp. 101-137.

61. Van Wyk, G.F.; Everard, D.A.; Midgley, J.J.; Gordon, I.G. Classification and Dynamics of a Southern African Subtropical Coastal Lowland Forest. South Afr. J. Bot. 1996, 62, 133-142. [CrossRef]

62. Reader, R.J.; Bricker, B.D. Value of Selectively Cut Deciduous Forest for Understory Herb Conservation: An Experimental Assessment. For. Ecol. Manag. 1992, 51, 317-327. [CrossRef]

63. Ng'andwe, P. Forest Classification, Zones and Classes-Basis for Industrial Processing; Ministry of Lands, Natural Resources and Environmental Protection, FAO: Lusaka, Zambia, 2012.

64. Zambia Forestry and Forest Industries Corporation. Annual Report; Zambia Forestry and Forest Industries Corporation: Ndola, Zambia, 2019.

65. Ng'andwe, P.; Muima-Kankolongo, A.; Banda, M.K.; Mwitwa, J.P.; Shakacite, O. Forest Revenue, Concession Systems and the Contribution of the Forestry Sector to Poverty Reduction and Zambia's National Economy. In A Draft Analytical Report Prepared for FAO in Conjunction with the Forestry Department and the Ministry of Tourism, Environment and Natural Resources; Forestry Department and the Ministry of Tourism, Environment and Natural Resources: Lusaka, Zambia, 2006.

66. Pelletier, J.; Hamalambo, B.; Trainor, A.; Barrett, C.B. How Land Tenure and Labor Relations Mediate Charcoal's Environmental Footprint in Zambia: Implications for Sustainable Energy Transitions. World Dev. 2021, 146, 105600. [CrossRef] 